\title{
A long non-coding RNA interacts with Gfra1 and maintains survival of mouse spermatogonial stem cells
}

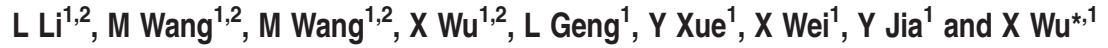

Spermatogonial stem cells (SSCs) are unique male germline stem cells that support spermatogenesis and male fertility. Long noncoding RNAs (IncRNA) have been identified as key regulators of stem cell fate; however, their role in SSCs has not been explored. Here, we report that a novel spermatogonia-specific IncRNA (IncRNA033862) is essential for the survival of murine SSCs. LncRNA033862 is expressed in early spermatogonia including SSC and was among 805 IncRNAs identified by global expression profiling as responsive to glial cell-derived neurotrophic factor (GDNF), a growth factor required for SSC self-renewal and survival. LncRNA033862 is an antisense transcript of the GDNF receptor alpha1 (Gfra1) that lacks protein coding potential and regulates Gfra1 expression levels by interacting with Gfra1 chromatin. Importantly, IncRNA033862 knockdown severely impairs SSC survival and their capacity to repopulate recipient testes in a transplantation assay. Collectively, our data provide the first evidence that long non-coding RNAs (IncRNAs) regulate SSC fate.

Cell Death and Disease (2016) 7, e2140; doi:10.1038/cddis.2016.24; published online 10 March 2016

Mammalian testes can produce thousands of sperm within the duration of a single heartbeat and millions of sperm per day. This output relies on spermatogenesis, a highly organized process encompassing proliferation and maturation of differentiating germ cells that ultimately derive from spermatogonial stem cells (SSCs). Surrounded by testicular somatic cells, SSCs represent male germline stem cells with the capability to develop into all types of male germline cells. Histological examination and transplantation experiments suggest that SSCs constitute a very rare cell population of the male gonad, encompassing approximately $0.01-0.03 \%$ of all cells in the mouse testis. ${ }^{1,2}$ The maintenance of a SSC pool and balancing SSC self-renewal and differentiation are essential for life-long spermatogenesis and fertility.

With the development of protocols for the long-term propagation of mouse SSCs as clump-forming colonies in vitro, ${ }^{3,4}$ multiple exogenous growth factors and chemicals have been identified that support the self-renewal and proliferation of mouse SSCs, including leukemia inhibitory factor, ${ }^{3}$ fibroblast growth factor 2 (FGF2), ${ }^{3,4}$ epidermal growth factor, ${ }^{4}$ insulin growth factor 1 and colony-stimulating factor $1,{ }^{5} \mathrm{Wnt}$ glycoproteins ${ }^{6}$ and low-dose $\mathrm{H}_{2} \mathrm{O}_{2}^{7}$, among others. Survival and self-renewal mammalian SSC in vivo and in vitro ${ }^{3,4,8}$ is dependent on glial cell line-derived neurotrophic factor (GDNF), which is secreted by the testis niche. GDNF has been used in vitro to support maintenance and expansion of SSCs or SSC-like cells in many species from rodents to primate including human. $^{9-13}$

Our understanding of molecular mechanisms controlling SSC fate has substantially increased within the past decade. GDNF signaling, alone or in combination with
FGF2 (basic FGF, bFGF) signaling, predominantly acts through modification of the activity of protein kinases, which include phosphoinositide-3 kinase-AKT (PI3K-Akt), mitogen-activated protein kinase/ERK kinase and Src family kinases, and subsequent changes in phosphorylation of downstream substrates ultimately affect gene expression. ${ }^{14,15}$ Additional evidence for factors involved in SSC self-renewal derives from experiments demonstrating that genetic activation of $\mathrm{H}$-Ras, a member of the protooncogene Ras family, and of cell cycle protein cyclin D2 can support SSC-like cell proliferation in vitro without supplement of exogenous cytokines, ${ }^{16}$ and that activation of AKT allows for the long-term proliferation of SSCs in the presence of FGF2 and GDNF. ${ }^{17}$ In addition, a number of coding genes have been shown critical for SSC self-renewal and survival; these include both genes subject to regulation by exogenous growth factors, for example, Etv5, Bcl6b; and genes not subject to such regulation, for example, Plzf, Foxo1. ${ }^{18-22}$ Recently, it has also become evident that microRNAs, including miR21, miR20 and 106a, miR221 and 222, and let7 family members have a role in maintaining a SSC pool and determining SSC fate. ${ }^{23-26}$

LncRNAs are transcripts of $>200$ nucleotides in length with little or no potential for translation. ${ }^{27}$ Mammalian IncRNAs have been found to be intrinsically functional, and increasing evidence points toward a role of IncRNAs as determinants of stem cell fate; specifically, as regulators of potency, selfrenewal and differentiation. ${ }^{28-30}$ Whether maintenance and differentiation of germline lineage stem cells depends on regulatory IncRNAs has not yet been investigated. Here, we have characterized IncRNA expression in SSCs by

\footnotetext{
${ }^{1}$ State Key Laboratory of Reproductive Medicine (SKLRM), Nanjing Medical University, Nanjing, Jiangsu, China

*Corresponding author: X Wu, State Key Laboratory of Reproductive Medicine (SKLRM), Nanjing Medical University, 504, Xianzhi Lou, 140 Hanzhong Road, Nanjing, Jiangsu 210029, China. Tel: +86 25 86862141; Fax: +86 25 86862141; E-mail: xinwu@njmu.edu.cn

${ }^{2}$ These are joint first authors.

Abbreviations: SPCs, spermatogonial progenitor cells; SSCs, spermatogonial stem cells; IncRNA, long non-coding RNA; GDNF, glial cell-derived neurotrophic factor; Gfra1, GDNF receptor alpha1; CHIRP, chromatin isolation by RNA purification; shRNA, small hairpin RNA

Received 22.10.15; revised 18.12.15; accepted 18.1.16; Edited by G Calin
} 
large-scale gene expression analysis, and report that a subset of IncRNA species in SSCs is regulated by GDNF, which is an essential growth factor required for SSC proliferation and maintenance. Among these, we have identified a novel spermatogonia-specific IncRNA (IncRNA033862) that controls SSC self-renewal and survival by regulation of the expression of Gfra 1, the glycosylphosphatidylinositol-linked cell surface receptor gene of GDNF.

\section{Results}

In vitro propagation of clump-forming germ cells with SSCs properties. To establish SSC cultures, we isolated CD90.2 (Thy1)-positive germ cells from the testes of neonatal Rosa26 transgenic mice using magnetic cell separation. These cells were propagated in vitro for $>3$ months in a serum-free defined medium, with continuous replenishment of the growth factors GDNF, GFRA1 and FGF2, following a previously established and reproducible protocol. ${ }^{31,32}$ The cultured germ cells formed clusters with typical grape-shaped morphology and were positive for PLZF (Zbtb16) and LIN28A (Figure 1a), which are markers of spermatogonial progenitor cells of the mouse testis. ${ }^{20,21,33}$ The expression profile of cultured germ cells was distinct from that of embryonic stem cells (ESCs) and STO feeder cells (feeder layer cells supporting ESC and SSC proliferation in vitro) and included pluripotency genes (Pou5f1, Lin28a), germline-specific genes (Ddx4 and Dazl) and SSC markers (Zbtb16 and Gra1), but not Gata1, which is restricted to somatic lineages of the testis (Figure 1b). Cultures established from postnatal germ cells support the maintenance and expansion of SSCs but do not reflect a homogeneous stem cell population. Rather, similar to spermatogonia in vivo, these cultures contain a subpopulation of true SSCs as defined by the capacity to restore spermatogenesis after transplantation into germ celldepleted recipient mouse testes ${ }^{34,35}$ We transplanted cell suspensions from SSCs cultures that had been maintained for 3 months into recipient testes and detected extensive colonization by beta-galactosidase reporter gene-positive donor cells (Figure 1c), confirming that the cultured clump-forming germ cells contained SSCs. Furthermore, in vitro proliferation of SSCs was dependent on GDNF: removal of GDNF from the culture medium for a period of 7 days resulted in a significant reduction in cell number (of $2.0 \times 10^{5}$ plated cells, an average of $0.6 \times 10^{5}$ remained after GDNF depletion) and changes in morphology with disappearance of grape shape clumps. In contrast, withdrawal of FGF2 for a week resulted in slower proliferation, but a net increase in cell number $\left(2.0 \times 10^{5}\right.$ versus $\left.3.6 \times 10^{5}\right)$, further confirming the crucial role of GDNF in maintaining SSC self-renewal and survival (Figure 1d and Supplementary Figure 1).

Genome-wide sequencing identifies IncRNAs with a potential role in SSC self-renewal and survival. Omitting GDNF from the medium for up to $18 \mathrm{~h}$ does not adversely affect the SSC potential of cultured Thy1-positive germ cells; therefore, temporary GDNF removal and subsequent replenishment can be used to identify GDNF-regulated genes involved in SSC fate determination. ${ }^{19}$ We used high-throughput sequencing to compare global RNA transcript profiles of two independent SSC cultures harvested in three different culture conditions that included normal culture in GDNF and FGF2 supplemented medium, after $18 \mathrm{~h}$ of GDNF depletion, and after an additional 8-h period of re-exposure to GDNF (see flow diagram in Figure 2a). Overall, normal cultured SSCs (N) contained more than twice as many IncRNA species (55924) than mRNA transcripts (17523); these included 21949 known IncRNAs from the NONCODE library (version 3.0) and 33975 predicted IncRNAs that were identified using Coding Potential Calculator ${ }^{36}$ (Figure 2b). Among mRNAs and IncRNAs with expression changes induced upon GDNF withdrawal (RNA transcripts with at least twofold up- or downregulation after $18 \mathrm{~h}$ of GDNF depletion compared with normal culture, $P<0.05)$, comparable proportions exhibited increases and decreases in level (1473/1154 versus 1000/1056; Figure 2c), suggesting that mechanisms of GDNF-dependent up- and downregulation of transcription in the genome of mouse SSCs affect mRNAs and IncRNAs similarly. A similar regulation pattern was also found after GDNF refreshment (Supplementary Figure 2a). Among the mRNAs with expression changes in response to GDNF removal were several genes previously identified as responsive to GDNF signaling, including Etv5, Bcl6b and Ccnd2 (Figure 2d). Known or predicted IncRNAs with expression changes after GDNF withdrawal included n266295, XLOC032444 and XLOC033862 (Figure 2e). For a more stringent analysis, we focused on transcripts that exhibited significant expression changes in response to both GDNF depletion and refreshment. A comparison of RNA species with at least a twofold change (mean reads from two replicates and Pearson correlation $>0.99, P<0.05)$ in expression level between control $(\mathrm{N}), 18 \mathrm{~h}$ GDNF withdrawal $(0 \mathrm{~h})$ and $8-\mathrm{h}$ GDNF re-exposure $(8 \mathrm{~h})$ identified 805 IncRNAs and 362 mRNAs (Figures $2 f$ and $g$ and Supplementary Figures $2 b-d$ ). These IncRNAs and mRNAs were randomly derived from all mouse chromosomes; most IncRNAs were either intergenic, intron antisense or intron sense (Supplementary Figures $3 a$ and b). More stringent criteria (false detection rate, $F D R<0.05$ ) identified 83 IncRNAs including XLOC033862 that exhibited distinct expression patterns following both GDNF withdrawal and refreshment (Supplementary Figure $3 \mathrm{c}$ and Supplementary Table 1).

LncRNA033862 is predominantly expressed in mouse SSCs and subject to GDNF signaling. Among the 805 IncRNAs with significant expression changes in response to GDNF withdrawal, IncRNA033862 (mus-XLOC_033862, termed IncRNA033862), a predicted IncRNA of 6384 bp that was not in the NONCODE ncRNA V3.0 library but predicted by Coding Potential Calculator, ${ }^{36}$ had the highest number of sequencing reads; this IncRNA ranked 13th in the number of sequencing reads among all IncRNAs identified in SSCs (Supplementary Table 1). We used Cufflinks to assemble transcripts from all data sets using the RefSeq gene annotation as a reference guide, ${ }^{37}$ and found that LncRNA033862 is transcribed from mouse chromosome 19 in antisense direction of the GDNF family receptor 
a

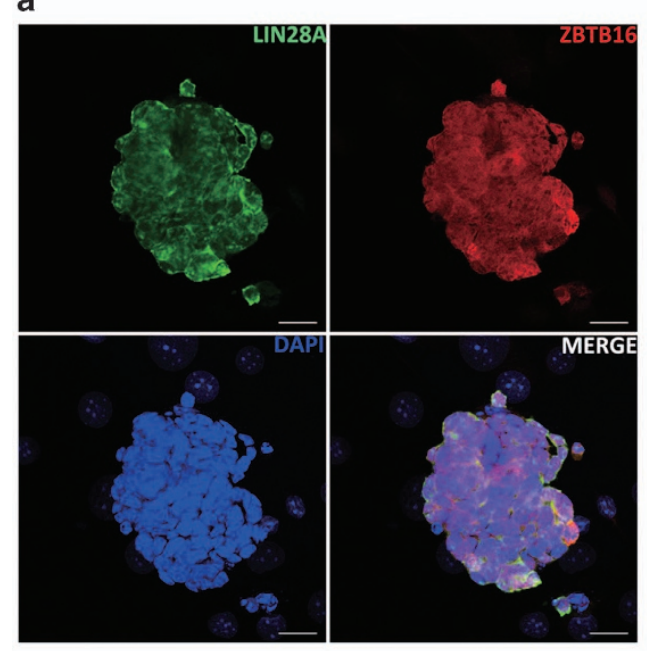

c

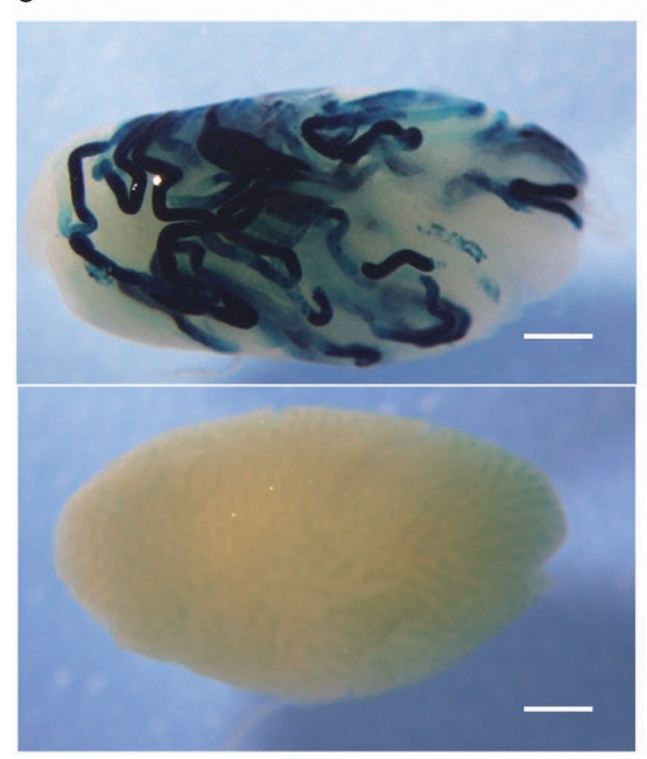

b

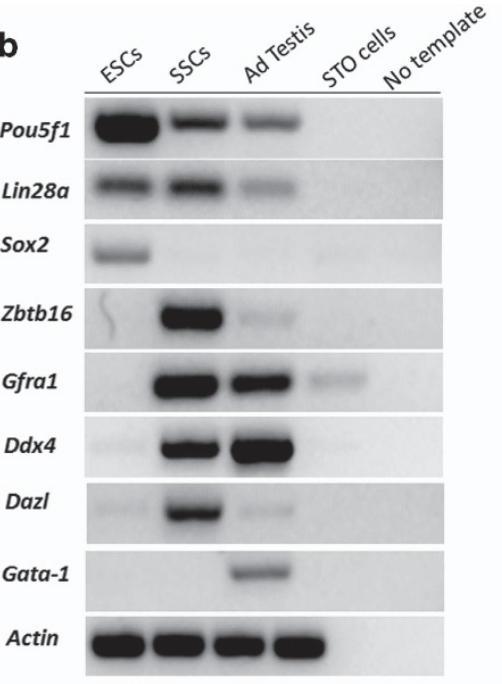

d

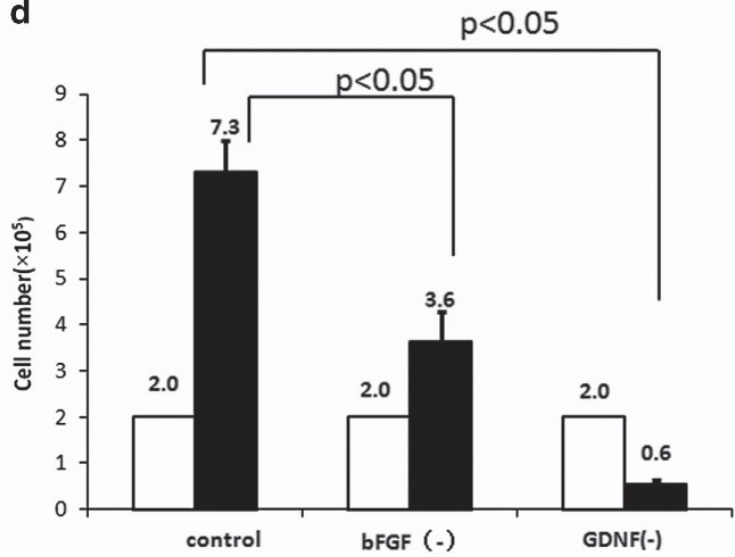

Figure 1 In vitro expansion of mouse SSCs. (a) SSC-enriched germ cells that were cultured in serum-free defined medium supplemented with GDNF and bFGF expanded into germ cell clumps that were positive for the pluripotency factor LIN28A, a cytoplasmic RNA binding protein, and the transcriptional factor ZBTB16, a marker for progenitor spermatogonia. Scale bar, $20 \mu \mathrm{m}$. (b) Cultured SSCs exhibited a distinct expression profile of pluripotency genes and germ cell lineage-specific markers but not somatic cell markers expressed in testis (RT-PCR analysis). (c) SSCs cultured for 3 months in vitro efficiently repopulated germ cell-depleted recipient testes after transplantation, evident from the presence of beta-galactosidase-positive, donor-derived spermatogenic colonies (upper panel). Transplantation of vehicle medium only was used as negative control (lower panel), scale bar, $1 \mathrm{~mm}$. (d) Proliferation of SSC in culture was dependent on GDNF but not bFGF. Cells plated at $2.0 \times 10^{5}$ per well into culture medium without bFGF continued to proliferate and expanded (average $3.6 \times 10^{5}$ per well versus $7.3 \times 10^{5}$ per well in normal culture medium). Cells plated into culture medium lacking GDNF did not proliferate resulting in a net loss of cells (average $0.6 \times 10^{5}$ per well) after 7 days culture. Control, normal culture medium contains both GDNF and bFGF. Error bars indicate S.D.

alpha (Gfra1) gene and contains a single predicted exon (Supplementary Figures $4 \mathrm{a}$ and $\mathrm{b}$ ). Using real-time reverse transcriptase polymerase chain reaction (RT-PCR; Supplementary Figure 4c), we confirmed that the relative expression level of IncRNA033862 was higher than that of other presumptive GDNF-regulated IncRNAs (036620, 023624, 032444; Figure 3a) and underwent significant changes in response to GDNF withdrawal (normal versus GDNF_-18 $\mathrm{h}, P<0.01$ ) and replenishment (GDNF_-18 $\mathrm{h}$ versus GDNF_+8 $\mathrm{h}, P<0.01$ ), with a decrease by almost $97 \%$ after $30 \mathrm{~h}$ of GDNF withdrawal (Figure $3 \mathrm{~b}$ ).
Tissue-specific expression analysis revealed that IncRNA033862 was highly abundant in mouse testis and brain (Figure 3c). LncRNA033862 expression in postnatal mouse testis was stage specific; high levels of transcript were present during the immediate postnatal period (postnatal days $(P)$ 1-3), a lower transcript level was detected at P7, and significantly lower levels after P10 $(P<0.01$, $)$, suggesting that IncRNA033862 was predominantly expressed by gonocytes or progenitor spermatogonia, which represent the earlier undifferentiated germ cell population in mouse testis from P1 to P7 (Figure 3d). To assess cell type-specific 
expression patterns of IncRNA033862 in mouse testis, we performed in situ hybridization of testis cryosections from 5-month-old adult mice using a 794-bp RNA probe specific for IncRNA033862 (Supplementary Figure 4c). Hybridization signal was restricted to spermatogonial cells attached to the basal membrane of seminiferous tubules a

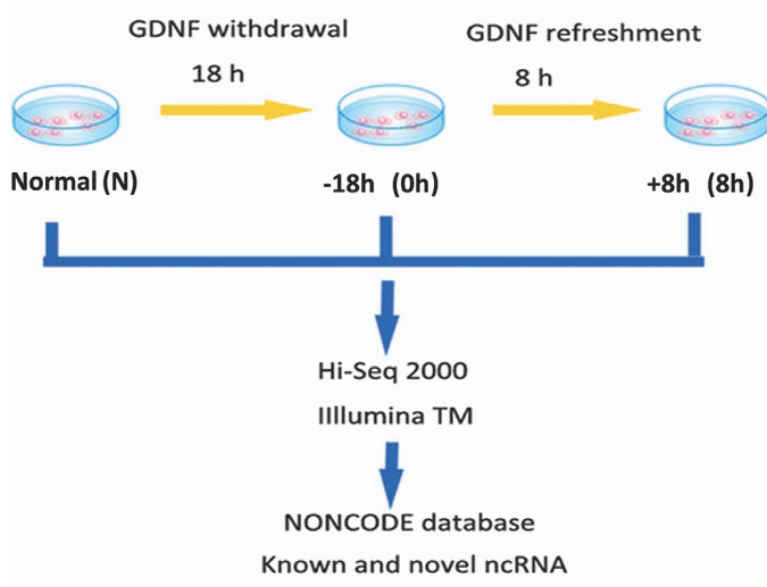

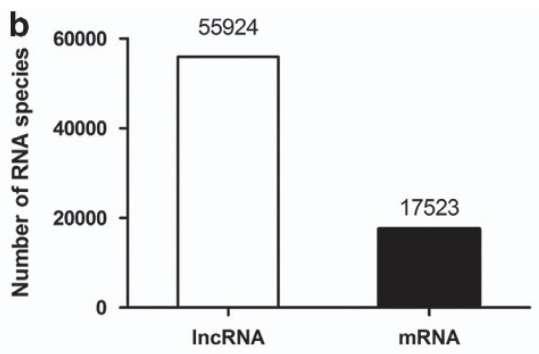

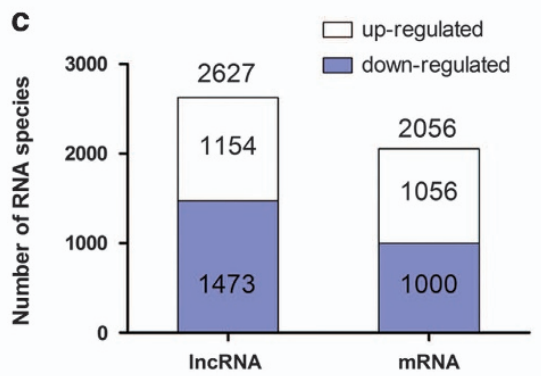

d
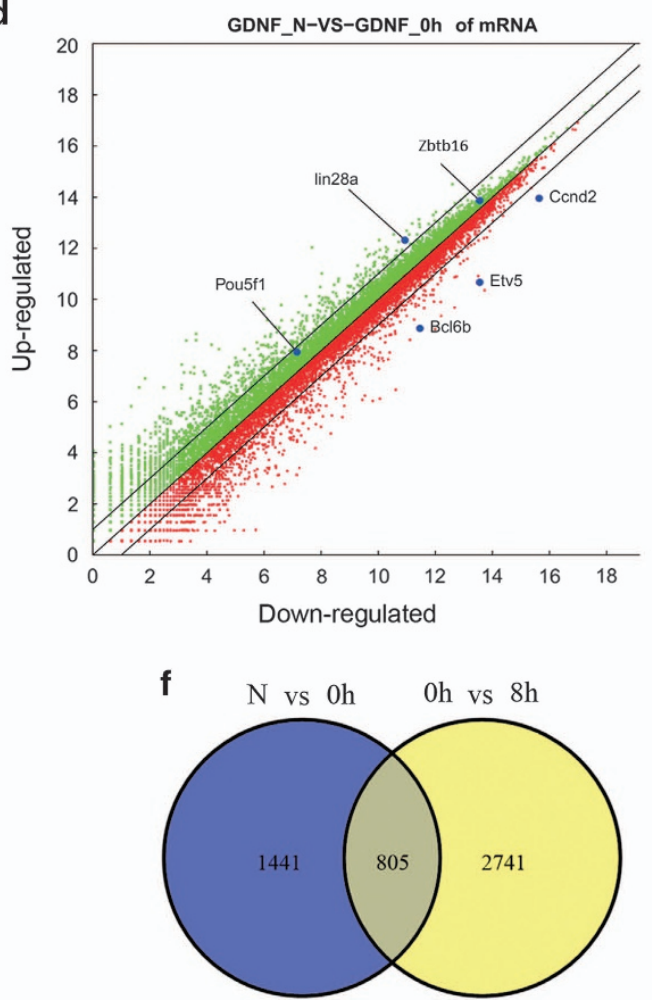

LncRNA
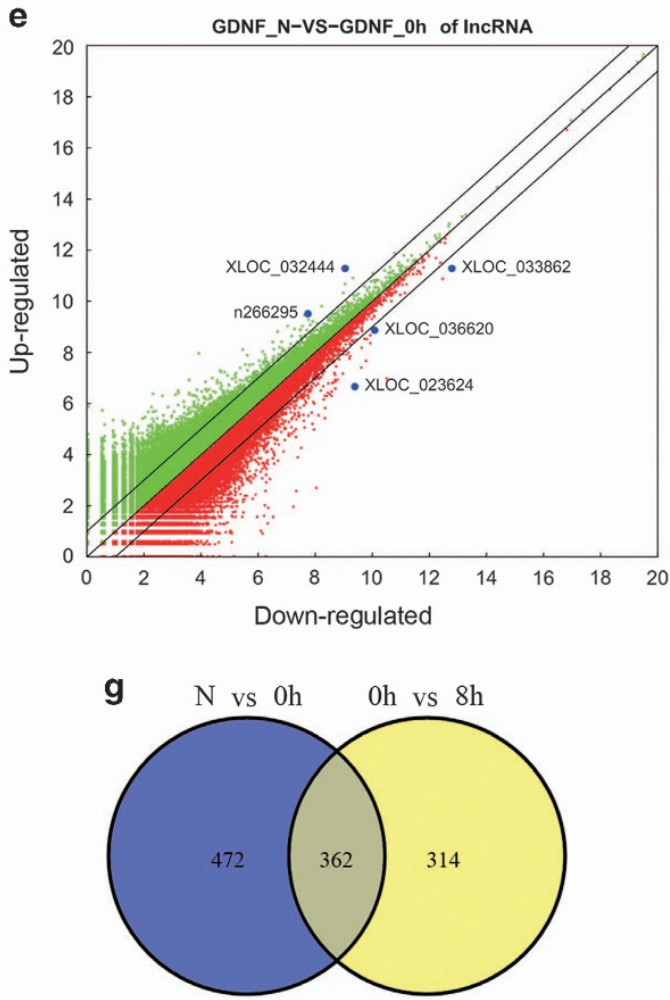

mRNA

Figure 2 Global profiling of LncRNAs and mRNAs regulated by GDNF in SSCs. (a) Experimental design. SSCs from two independently established cultures were collected at three time points of GDNF exposure (N, in normal culture medium; $0 \mathrm{~h}$, after $18 \mathrm{~h}$ of GDNF depletion; $8 \mathrm{~h}$, after $8 \mathrm{~h}$ of replenishing GDNF). (b) Total number of IncRNA and mRNA species identified in SSCs. (c) Number of IncRNA and mRNA species that were significantly (at least twofold; $P<0.05$ ) upregulated (no fill) and downregulated (blue fill) in response to GDNF depletion. (d and e) Scatter plots of all IncRNAs and mRNAs identified in SSCs. A log2 calculation was used to normalize each transcript expression level. RNA species that were up- and downregulated after GDNF depletion are shown in red and green color, respectively. (f) Venn diagram analysis of IncRNA and mRNA species with significant (at least twofold; $P<0.05)$ expression changes after GDNF withdrawal ( $N$ versus $0 \mathrm{~h})$ and $(\mathbf{g})$ replenishment $(0 \mathrm{~h}$ versus $8 \mathrm{~h})$. The number of IncRNA species with expression changes in response to GDNF withdrawal and replenishment was more than twofold higher than that of mRNA species (805 versus 362 ) 

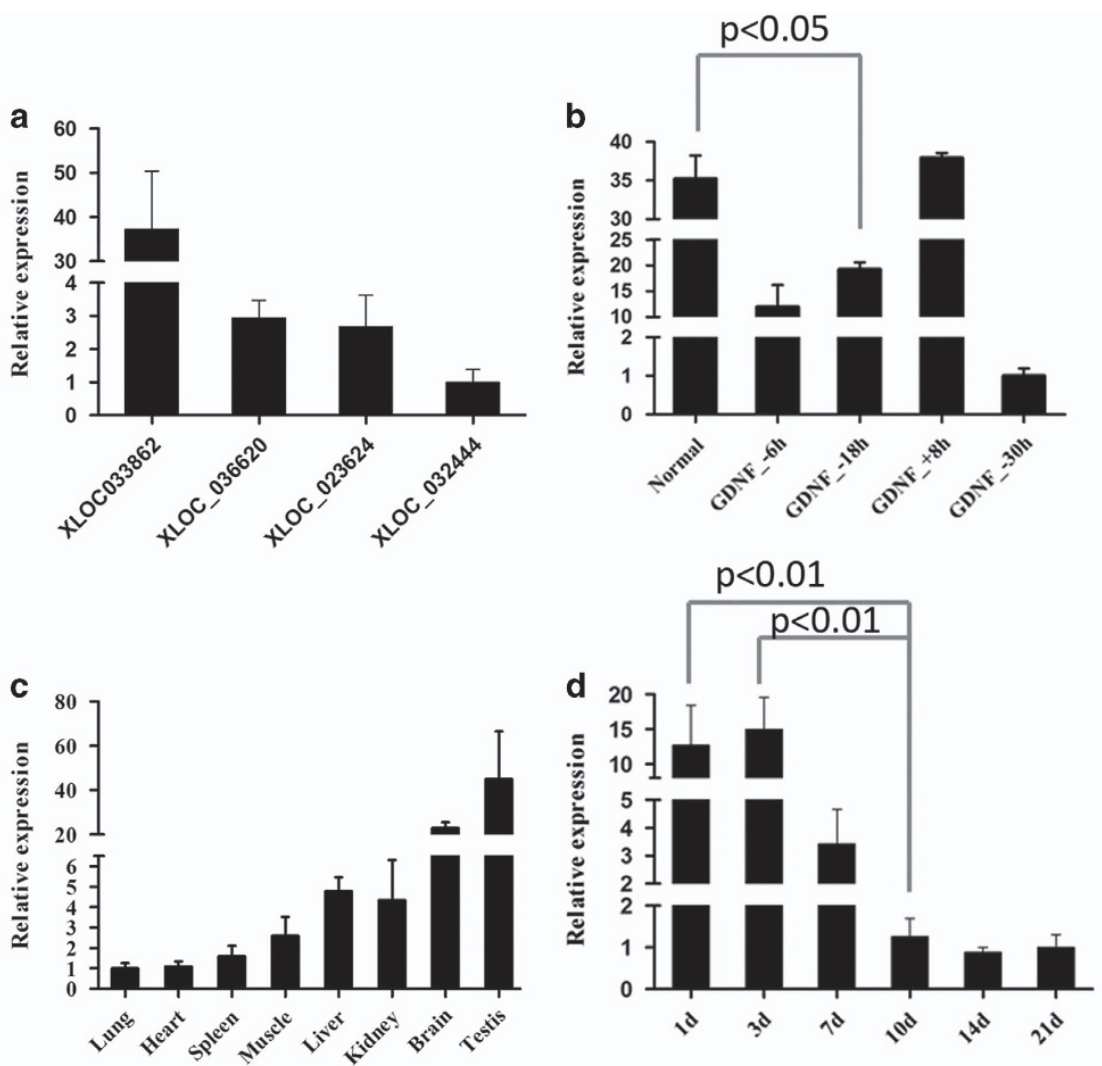

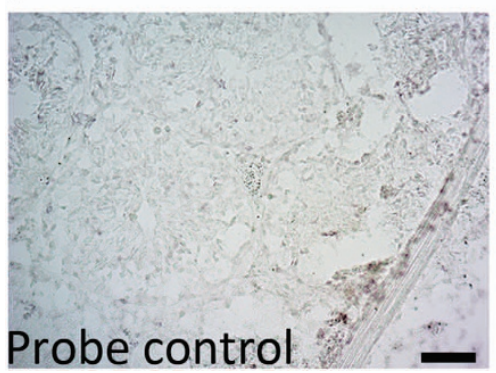

f

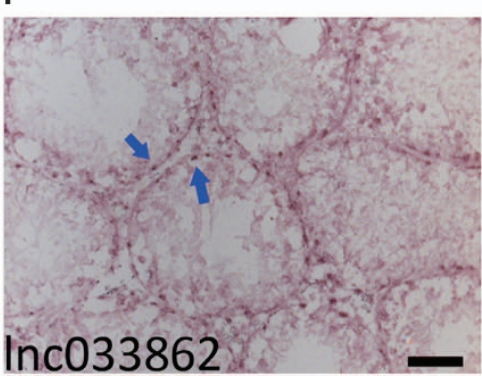

g

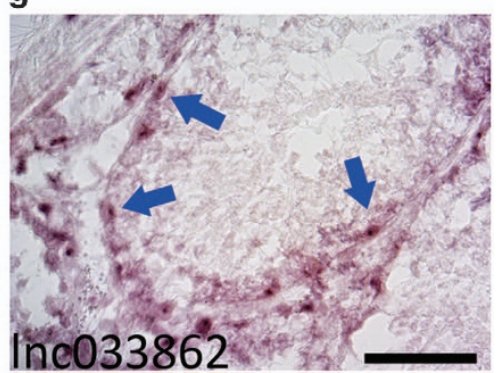

Figure 3 LncRNA033862 is highly expressed in cultured SSCs and in spermatogonia. Quantitative real-time RT-PCR confirmed (a) higher relative expression of IncRNA033862 in SSC compared with other predicted IncRNAs (Inc036620, Inc023642 and Inc0322444) that exhibited expression changes in response to GDNF withdrawal. (b) Changes in relative expression of IncRNA033862 after GDNF withdrawal and replenishment. (c) Tissue-specific expression analysis reveals high expression levels of IncRNA033862 in adult mouse testis and brain tissue. (d) Changes in IncRNA033862 transcript levels in mouse testis during the first 3 weeks of postnatal development; transcript levels were highest from postnatal day (P) 1 to P7 and significantly decreased after P10 ( $P$-value $<0.01)$. (e) In situ hybridization identifies cell type-specific expression of IncRNA033862 in spermatogonia on the basal membrane of seminiferous tubules, and the complementary sequence to the probe was used as sense control. (f) Predominantly nuclear signal was found at lower magnification and $(\mathbf{g})$ higher magnification. Error bars indicate S.D. Scale bar $=50 \mu \mathrm{m}$

(Figures 3e-g and Supplementary Figure 5), suggesting that IncRNA033862 could be a spermatogonia-specific IncRNA.

LncRNA033862 localizes to the nucleus and lacks translation potential. To identify the subcellular localization of IncRNA033862, we isolated nuclear and cytoplasmic RNA species from SSCs after cellular fractionation (Supplementary Figure 7a). Similar to the small nuclear RNA U6, IncRNA033862 was abundant in the nuclear fraction of SSCs (Figure 4a). We next examined the coding potential of IncRNA033862, which was identified as a non-coding sequence using Coding Potential Calculator. ${ }^{36}$ Generally, it is believed that translation is actively associated with polysomes. ${ }^{38,39}$ Therefore, we performed cell polysome separation and harvested RNAs from ribonucleoprotein (RNP), $40 \mathrm{~s}$ to $80 \mathrm{~s}$ ribosome, and polysome fractions isolated from SSCs by gradient centrifugation and fractionation (Figure 4b). Western blot analysis confirmed the absence of tubulin and ribosomal protein L22 (RPL22) from the polysome and RNP fractions, respectively (Figure 4b), validating separation efficiency. Amplification of transcripts associated with each polysomal fraction revealed that IncRNA033862 transcript was predominantly associated with RNPs but not ribosomes or polsysomes (Figure 4c), 

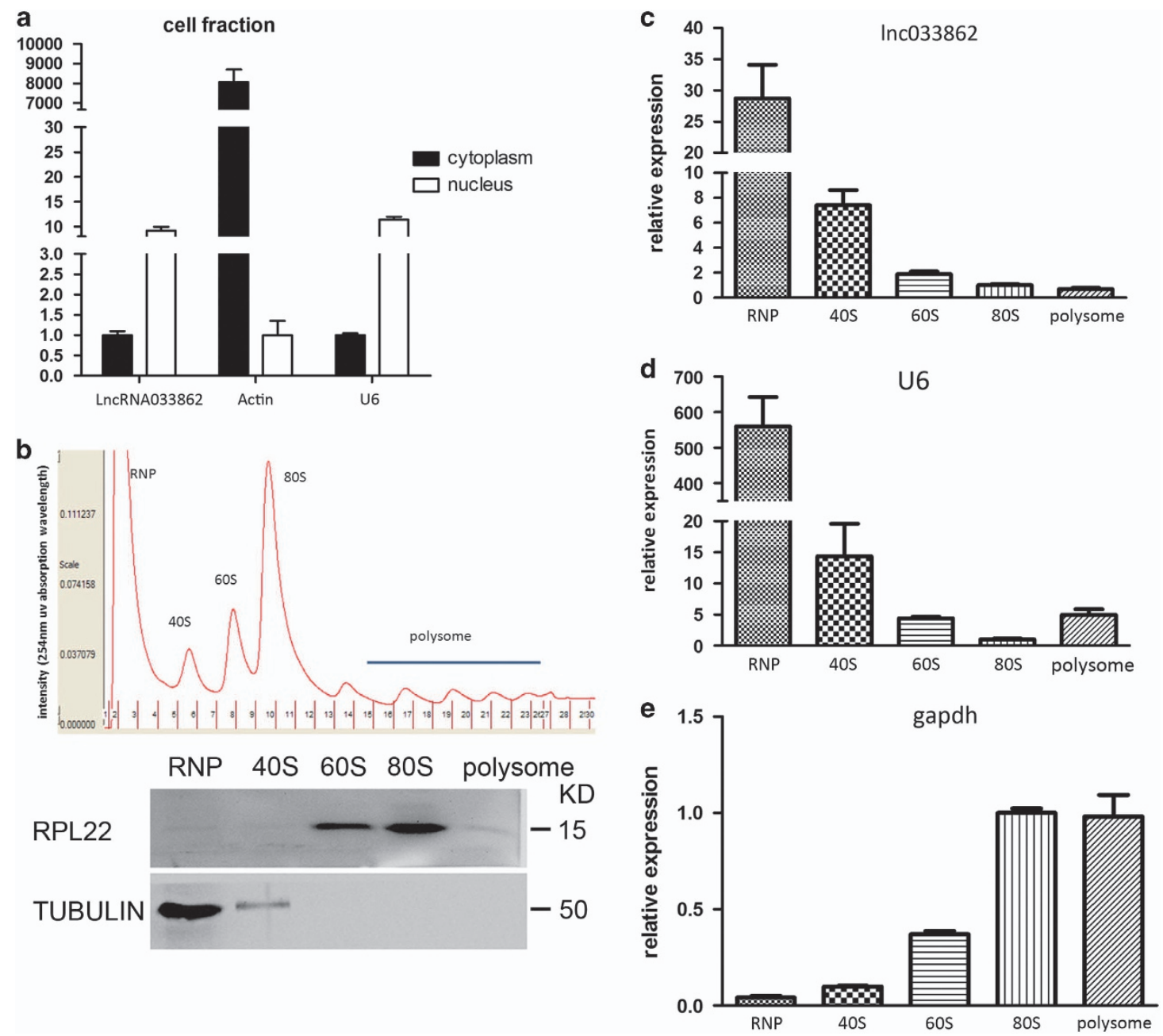

Figure 4 LncRNA 033862 localizes to the nucleus in SSCs and does not have translational potential. (a) Quantitative RT-PCR confirms that IncRNA033862 is predominantly found in the nuclear but not cytoplasmic fraction of SSCs. Small nuclear RNA U6 transcript and actin mRNA served as positive controls for a nuclear RNA and a translated mRNA, respectively. (b) Polysome profile of fractions from SSC. UV-absorbance peaks correspond to ribonucleoprotein particles (RNP), free ribosomal subunits (40S and 60S), 80S monosomes, and polysomes, separation of polysome fractions was confirmed by western blot analysis of ribosomal protein L22 (RPL22; positive control for polysome protein) and tubulin (positive control for RNP). (c-e) Quantitative real-time RT-PCR confirms the association of LncRNA033862 with RNP but not ribosomal subunits or monosomes. Small nucleus RNA U6 and GAPDH mRNA served as positive control for RNA species known to associate with RNP and ribosomes, respectively. Error bars indicate S.D.

resembling the known nuclear transcript small nuclear RNA U6 in distribution (Figure 4d). In contrast, Gapdh mRNA, which served as a positive control for a translated transcript, was almost absent from the RNP fraction and associated with ribosome and polysome fractions (Figure 4e). Based on these findings, we propose that IncRNA033862 is an untranslated transcript without protein coding potential.

LncRNA033862 is an antisense transcriptional regulator of Gfra1. LncRNA033862 maps to Gfra1, which encodes the GDNF co-receptor expressed in SSCs. ${ }^{40}$ Specifically, IncRNA033862 is a partial antisense transcript of Gfra1 that initiates 3-kb downstream of Gfra1 exon 9 and includes exon 9 (2935 bp) and the intronic region between exons 8 and 9 (449 bp; Figure 5a; Supplementary Figures 4a and b). Global transcript analysis by RNA sequencing revealed that mRNA levels of Gfra 1 paralleled those of IncRNA033862 after GDNF removal and replenishment, with a decline in reads after $18 \mathrm{~h}$ of GDNF depletion and increase after GDNF replenishment (Figure $5 \mathrm{~b}$ and Supplementary Figure 6a); these changes in Gfra1 expression were confirmed on both the mRNA and protein levels (Figures $5 \mathrm{c}$ and d). Furthermore, there was a significant correlation $(P<0.05)$ of Gfra1 and IncRNA033862 expression in vivo (Supplementary Figure $6 b)$.

It has been demonstrated that naturally occurring nuclear antisense transcripts can regulate gene expression by RNA-DNA interaction or RNA-protein interaction. ${ }^{27}$ To explore whether IncRNA033862 was potentially associated with and involved in Gfra1 chromatin modification, we performed chromatin isolation by RNA purification (ChIRP; see flow diagram in Figure 5e). Cross-linked RNP-chromatin complexes were isolated after hybridization to tiled labeled antisense oligonucleotides designed against IncRNA033862 (Supplementary Figure 4c), followed by detection of captured RNA species and chromosomal segments. RT-PCR analysis of RNA species captured using two pools of five antisense 
a

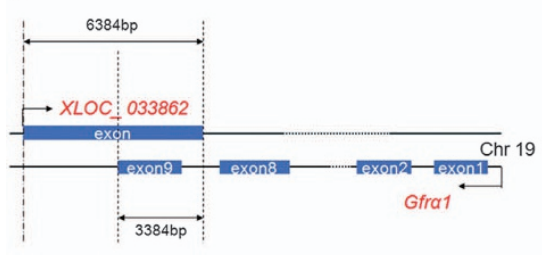

b

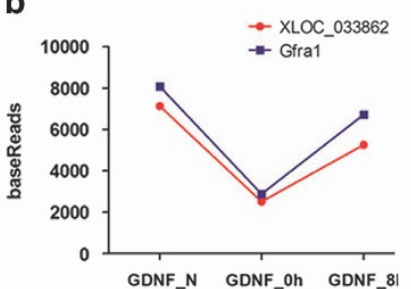

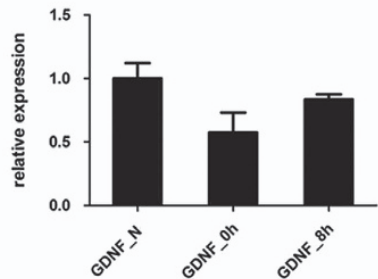

d

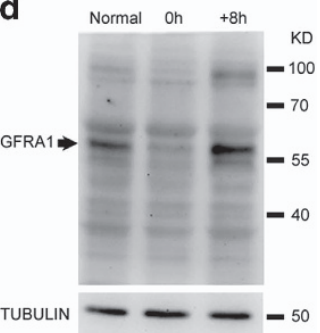

e

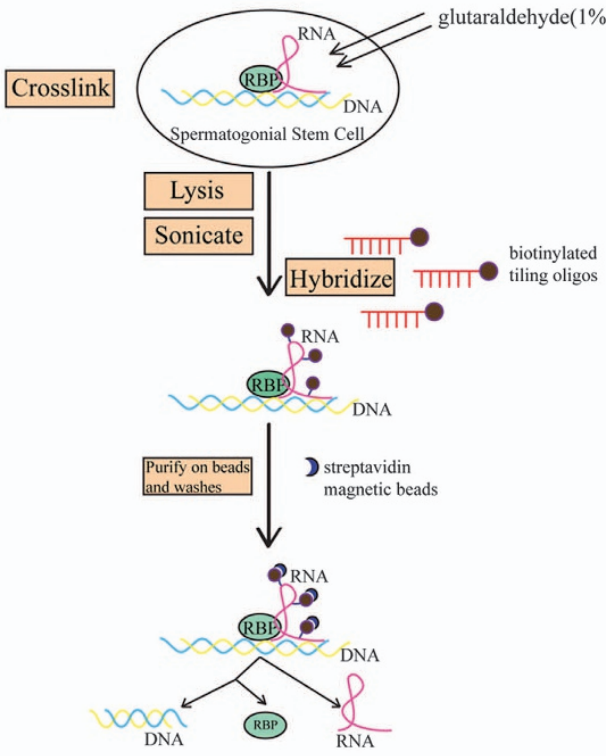

f 1.5 $\mathbf{B}$ Gapdh

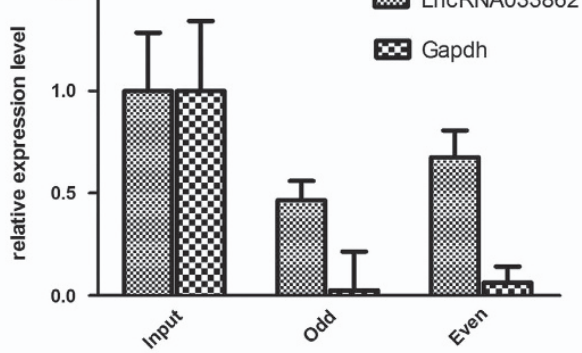

9 VI:155bp I:168bp III:137bp III:162bp IV:173bp V:153bp

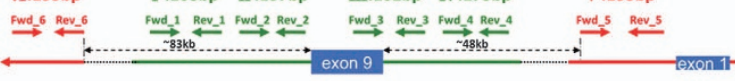

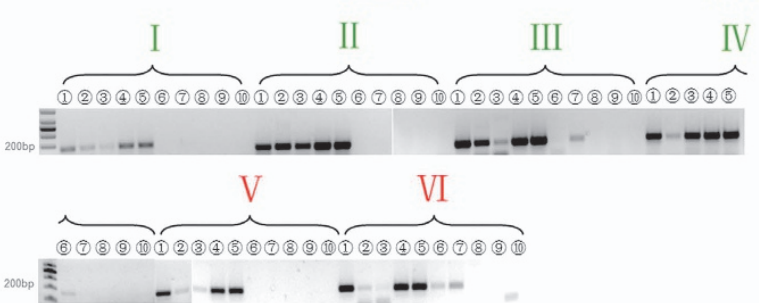

Figure 5 LncRNA033862 interacts with Gfra 1 (a) LncRNA033862 is an antisense IncRNA of Gfra1, which encodes GDNF family receptor alpha. The 6384-bp sequence of IncRNA033862 is transcribed from the opposite strand of Gfra1 covering intron 9 and exon 9. (b) Changes in IncRNA033862 and Gfra1 transcript levels in SSC in response to GDNF depletion and replenishment. Yaxis, number of reads identified by global gene expression profiling. (c-d) Gfr 1 transcript and protein levels were further validated by RTPCR and western blotting, respectively. (e) Experimental outline for ChIRP analysis. (f) ChIRP analysis demonstrates that IncRNA033862 interacts with the chromosomal region encoding Gfra1 in SSCs. Biotinylated oligonucleotides (probes, total number $=10$ ) tiling the IncRNA033862 transcript were combined in even and odd-numbered pools. Each oligonucleotide pool specifically precipitated the IncRNA033862 transcript but not GAPDH mRNA transcript. (g) Five sets of PCR primers were designed to amplify those Gfra1 DNA sequences that co-precipitated with the tiling oligonucleotides. At least one pool was enriched for all Gfra1 sequences contained within the overlapping regions with IncRNA033862, but not sequences outside the region of complementarity. I and II: PCR primers directed against putative IncRNA033862 binding sequences located 2.3 and 0.6-kb downstream of exon 9 of the Gfra1 gene, respectively; III and IV: primers detecting a sequence covering exon 9 of Gfra1; V: primers detecting a sequence at approximately 48-kb upstream of Gfr 1 gene; Vl: primers detecting a sequence at approximately 83-kb downstream of Gfr 1 gene. PCR products were amplified using the respective primers indicated on top of the panel from the following samples: (1) input DNA, (2) and (3) DNA co-precipitated with odd and even-numbered pools of probes, (4) and (5) cell lysates, (6) to (9) washing buffers, and (10) water control. Error bars indicate S.D. for above statistic data

oligonucleotides each revealed enrichment of IncRNA033862, whereas a control Gapdh mRNA was not captured (Figure 5f). We next amplified genomic DNA captured by ChIRP using oligonucleotides directed against regions of Gfra1 that overlapped with or excluded the sequence of IncRNA033862. Significantly, at least in one set of tiling antisense oligocaptured DNAs, the regions of Gra1 gene overlapping with IncRNA033862 were much more enriched than nonoverlapping regions (Figure $5 \mathrm{~g}$; this was further verified by quantitative PCR, Supplementary Figure $8 \mathrm{a}$ ), suggesting that IncRNA033862 transcripts interact with Gfra1 at regions of complementarity. We also evaluated potential interactions of IncRNA033862 with proteins by performing protein mass spectrometry on both sets of oligo-captured cross-linked
RNP-chromatin complexes. These analyses identified only a single secretory carrier membrane protein SCAMP1 (Supplementary Figures 8b and c).

Knockdown of IncRNA033862 impairs self-renewal and survival of mouse SSCs in vitro. To assess the effect of IncRNA033862 knockdown in SSCs on Gfra1 expression and cell fate, we designed two different small hairpin RNAs (shRNAs) against IncRNA033862; both sh663 and sh1894 were directed against sequences of IncRNA033862 not contained within the presumptive region of interaction between IncRNA033862 and Gfra1 (Supplementary Figure 4c). Transduction of cultured SSCs with a lentivirusencoding sh663 resulted in a reduction of IncRNA033862 
transcript by $30 \%$ and a modest reduction of Gfra 1 expression levels $(P>0.05)$. In contrast, transduction with a lentivirus-encoding sh1894 produced a significant reduction of IncRNA033862 transcript levels by $65 \%(P<0.05)$ in SSC cultures, indicating that this construct mediates effective knockdown of IncRNA033862, taking into account that not all cells were transduced. In these cultures, we observed a concomitant significant reduction of Gra1 mRNA levels by $60 \%(P<0.01$; Figures $6 a$ and $b)$ and reduced GFRA1 protein levels (Supplementary Figure $7 \mathrm{~b}$ ). These results show that IncRNA033862 is a positive regulator of Gfra1 transcription in SSCs.

After 7 days of culture, SSC cultures transduced with lentiviruses encoding sh663 or sh1894 had significantly lower cell numbers than control cultures $(76.7 \%$ and $35.6 \%$ of control cell numbers, respectively; Figure $6 \mathrm{c}$ ). FACS analysis revealed a larger proportion of apoptotic cells compared with control cultures (Figures 6d-f), with a significant increase of apoptotic cells and combined dead and apoptotic cells (Figures 6g-i, Supplementary Figure 7c) 4 days after lentiviral transduction. Cell cultures transduced with shRNA1894encoding lentivirus underwent substantial changes in morphology, manifesting with an initial reduction of colony size followed by disappearance of grape-shaped clusters (Figures 6j and k), and a significant decrease in total cell number compared with control cultures (Figure 6c). Furthermore, we found that transcripts of genes associated with SSC self-renewal, including Bcl6b Ccnd2, and Pou5f1 (Oct4), were significantly downregulated, whereas transcript levels of genes associated with differentiation, such as Stra8, Sypc1 and Kit, were extremely low and not affected by IncRNA033862 knockdown; transcripts of genes associated with homing were unchanged (beta1-integrin) or reduced (Cxcr4; Supplementary Figure 9). In summary, these data suggest that knockdown of IncRNA033862 impairs selfrenewal and maintenance of SSCs.

Knockdown of IncRNA033862 impairs the capacity of SSC to regenerate spermatogenesis after transplantation. SSC cultures contain a sub-population of true SSCs that are defined by their capacity to restore spermatogenesis in germ cell-depleted recipient testes after transplantation. ${ }^{35}$ To assess if IncRNA033862 knockdown affected properties of this sub-population, we performed transplantation assays into recipient testes. ${ }^{41}$ We transplanted cell suspensions of SSC cultures, in which overall transcript levels of IncRNA033862 were reduced up to $65 \%$ after transduction with a lentivirusencoding sh1894, into the testes of recipient male mice in which endogenous spermatogenesis had been abolished. We observed significantly fewer donor SSC-derived germ cell colonies in testes that had received transplants from SSC cultures subject to IncRNA033862 knockdown compared with testes receiving cells from SSC cultures transduced with control lentivirus $(2.5 \pm 0.6$ versus $13.8 \pm 2.6, \quad P<0.01$; Figure 7a). Histological analysis showed that seminiferous tubules with donor-derived colonies from either IncRNA033862 knockdown or control SSC cultures exhibited a full range of germ cell development (Figure 7b). These findings demonstrate that knockdown of IncRNA033862 in SSC cultures via lentiviral transduction significantly reduces the number of true SSCs in these cultures; however, a subset of SSCs remain that are capable of restoring the full range of spermatogenesis. These may reflect cells that were not transduced.

In summary, we have identified the first IncRNA transcript that is important for the self-renewal function of SSCs. We propose that transcription of Gfra1 requires a normal level of IncRNA033862, which is present under physiological conditions in the testis niche and depends on GDNF signaling (Figure 7c). The absence of GDNF from niche or culture causes a reduction in IncRNA033862 transcript level, resulting in transcriptional silencing of Gfra1 (Figure 7d).

\section{Discussion}

Growing evidence has revealed a major involvement of IncRNAs in stem cell fate determination, including maintaining self-renewal of stem cells and lineage differentiation. ${ }^{28-30}$ Here, we have applied high-throughput RNA sequencing to identify IncRNAs with a potential regulatory role in SSCs. Of 55924 IncRNA transcripts, we identified 805 IncRNA transcripts in SSCs subject to transcript level changes in response to GDNF, which is an essential growth factor required for SSC self-renewal. These represent approximately $1.4 \%$ of the total sequenced known and predicted IncRNAs, suggesting a potential biological significance of these IncRNAs in GDNF-dependent self-renewal of SSCs.

To promote spermatogonial self-renewal, GDNF signals through a receptor complex that includes GDNF family receptor a1 (GFRA1). GFRA1 has been considered a cell surface marker suitable for the identification of SSCs in mouse testes. GFRA1-positive single spermatogonia have been considered the 'actual stem cells' of the testes that have the greatest potential to support normal spermatogenesis, ${ }^{42}$ and SSCs have been successfully enriched using cell sorting with an anti-GFRA1 antibody. ${ }^{43}$ Genetic loss of Gfra 1 significantly reduced the self-renewal of SSCs in neonatal mouse testis, ${ }^{44}$ and in vitro reduction of Gfra 1 transcript negatively affected the proliferation of SSCs. ${ }^{40}$ Results of previous studies have suggested a feed-forward mechanism in which expression of the co-receptor Gfra1 is upregulated by GDNF signaling but the regulatory mechanism remains undefined. Although a mounting body of evidence indicates that IncRNAs influence the fate decisions of stem cells in other lineages, their role in any spermatogonial subtype has remained undefined. Here, we have identified IncRNA033862, a GDNF-regulated antisense IncRNA transcript located within Gfra1 that is predominantly expressed in spermatogonia including SSCs of the mouse testis. We find that IncRNA033862 regulates SSC survival and proliferation by RNA-DNA interaction and mediates transcriptional activation of Gfra1, the receptor gene of GDNF.

Nuclear IncRNAs encompass natural antisense transcripts, defined as RNA molecules that are transcribed from the opposite DNA strand of a transcript and overlap in part with the sense RNA. ${ }^{27}$ The majority of natural antisense transcripts that have been identified in the mammalian genome are nonprotein-coding. ${ }^{27} \mathrm{We}$ find that IncRNA033862 represents such a nuclear, non-coding antisense transcript of Gfra1. Although many studies have demonstrated that antisense transcripts 
mediate both transcriptional activation or silencing of the associated coding gene, ${ }^{45-49}$ the mechanisms by which IncRNAs exert this regulatory control on gene expression remain elusive. Presumably, IncRNAs may affect gene expression and protein translation by interacting with RNAs transcripts, miRNAs or protein components of

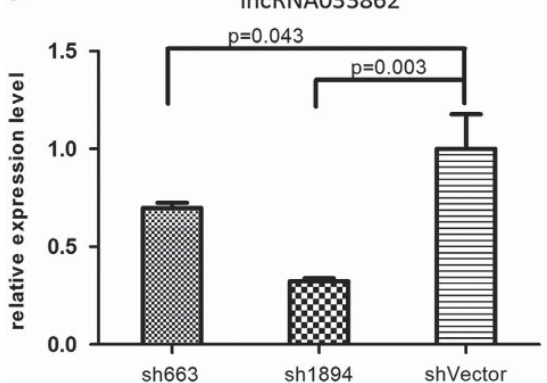

d

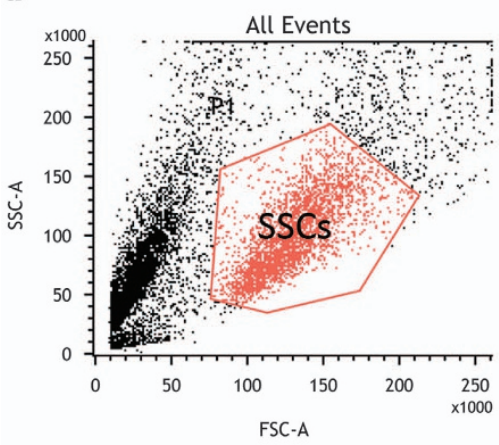

g

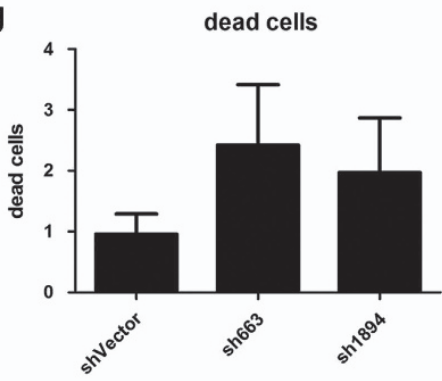

j

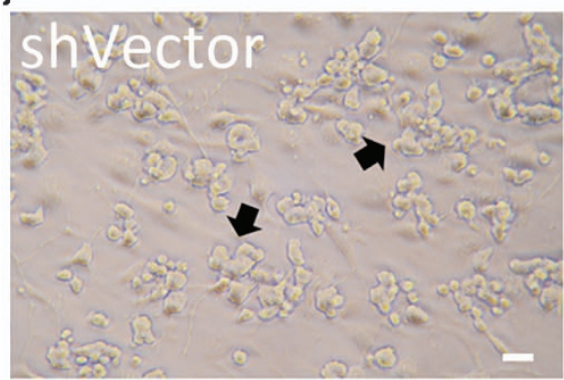

b

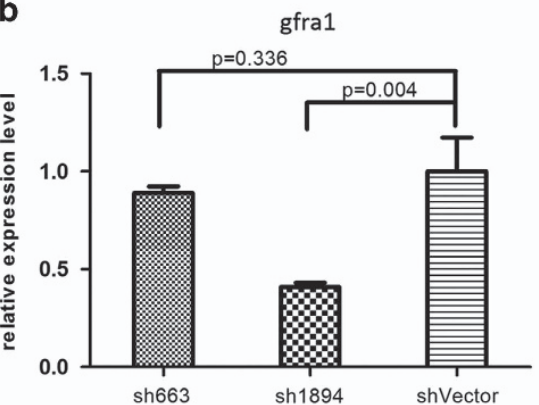

e

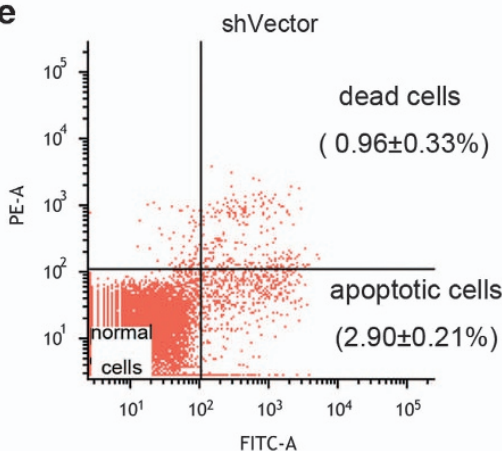

h

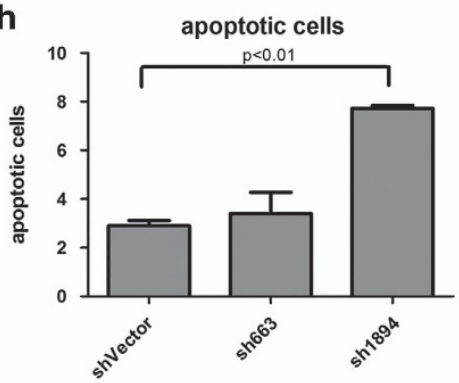

C

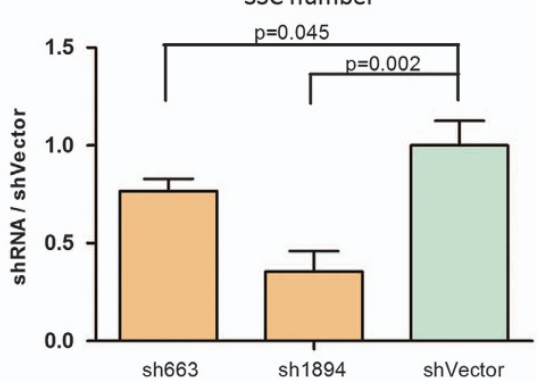

f
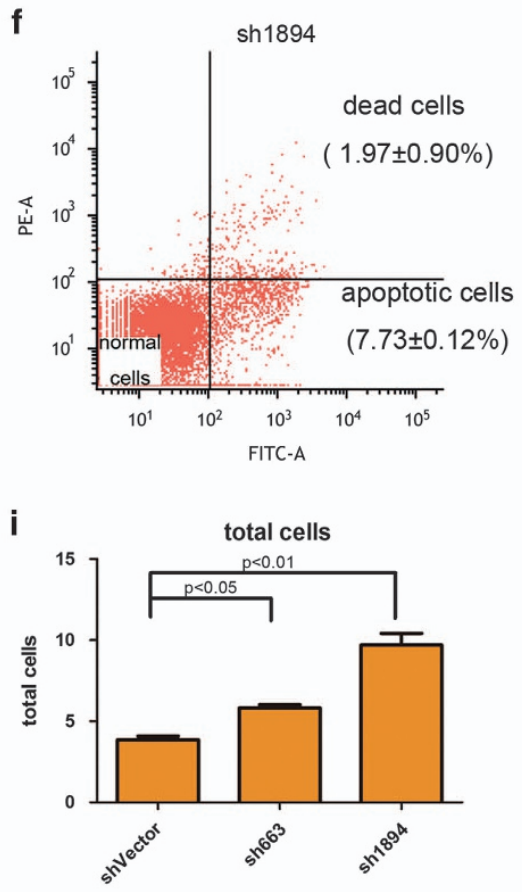

k

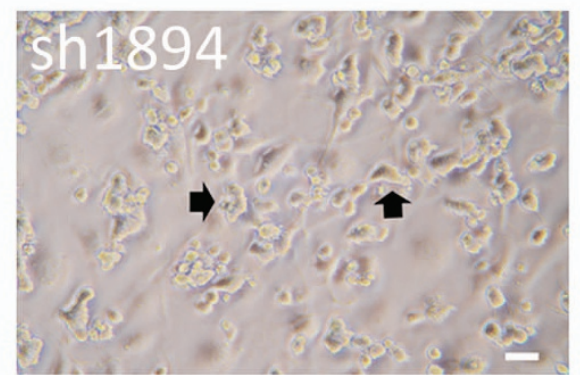

Figure 6 Knockdown of LncRNA 033862 impairs the survival and proliferation of SSCs. (a) In vitro lentivirus-mediated knockdown resulted in a reduction of IncRNA033862 transcript levels by $30 \%$ with shRNA663, and by $65 \%$ by shRNA1894, and a corresponding reduction of Gfra 1 transcript levels (b) to $88.9 \%$ with shRNA663, and to $40.9 \%$ with shRNA1894. (c) Significant reduction of total cell number in SSC cultures 7 days after transduction with shRNA663 and shRNA1894 compared with vector alone (shVector). FACS analysis of SSCs gated according to forward and side scatter as indicated in (d). (e and f) Compared with shVector transfection, knockdown IncRNA033862 by sh1894 resulted in an increase of apoptotic cells in SSC cultures. (g) Lentiviral transduction of SSCs with shRNA663 or shRNA1894 resulted in an increased number of dead cells and ( $h$ ) significantly higher total numbers of apoptotic cells in SSCs transduced with shRNA1894. (i) Both shRNA663 $(P<0.05)$ and shRNA1894 $(P<0.01)$ induced a significant increase in the number of abnormal (dead and apoptotic) cells. (j) Morphological changes in SSC cultures after vector control transfection and (k) shRNA1894 induced knockdown of IncRNA033862. Cell clumps became visibly smaller and dissociated within one week following transduction (scale bar $=20 \mu \mathrm{m}$ ). Error bars indicate S.D. for above data 


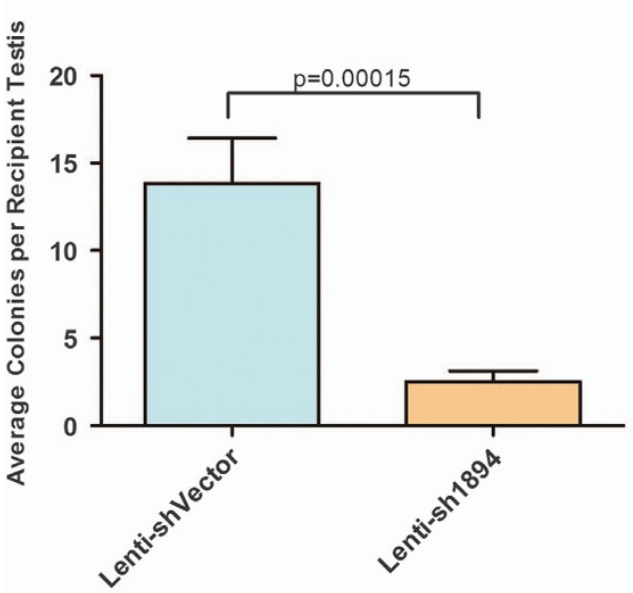

C

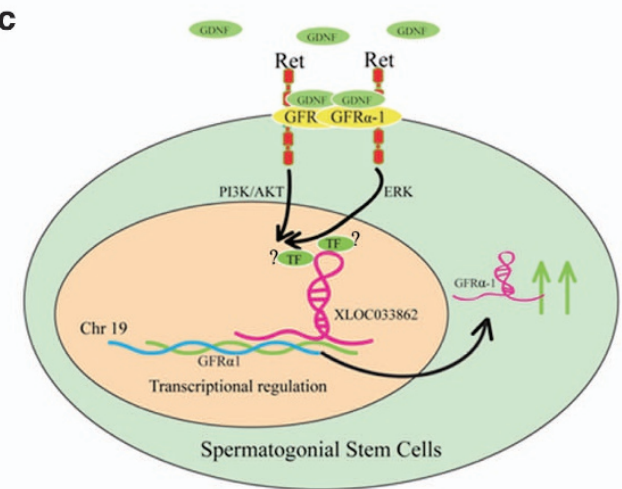

b
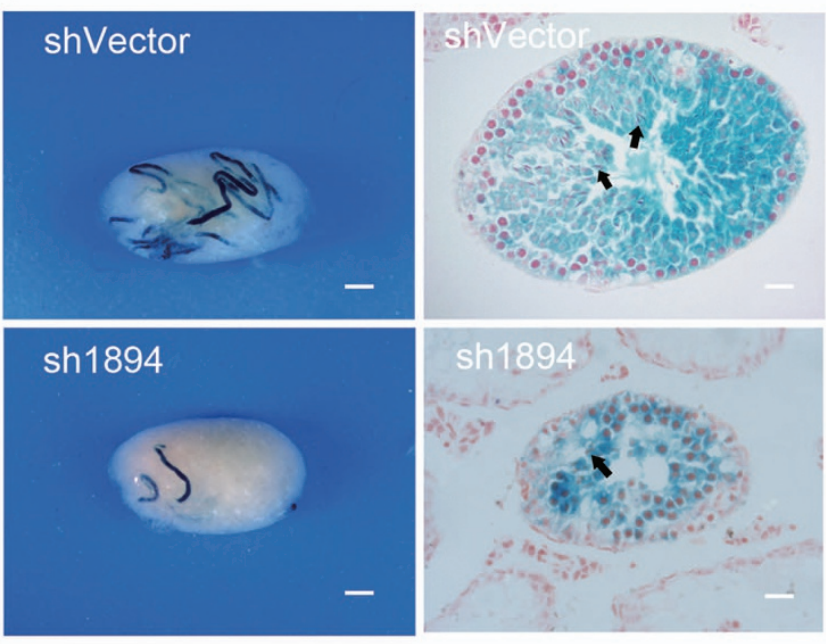

d

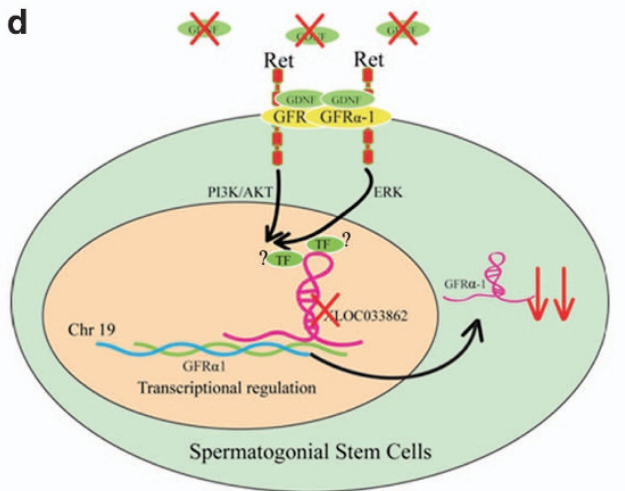

Figure 7 Reduced repopulation capacity of SSCs after IncRNA033862 knockdown. (a and b) SSCs transduced with shRNA1894-encoding lentivirus formed significantly fewer spermatogenic colonies in recipient testes than SSCs transduced with vector control, scale bar $=1 \mathrm{~mm}$. Data are from three independent transplantation experiments; in total, control vector lentivirus transduced SSC were transplanted into 21 testes, and sh1894 lentivirus transduced SSC into 22 testes. Donor-derived colonies exhibited a full range of germ cell development, including mature spermatids (black arrows, scale bar $=1 \mathrm{~mm}$ for left panel and $20 \mu \mathrm{m}$ for right panel), irrespective of IncRNA033862 knockdown. (c) Proposed model for the regulation of mouse SSC self-renewal and maintenance by IncRNA033862. Under normal physiologic conditions in the testes, exogenous growth factor GDNF binds to its receptor GFRA1 and RET and stimulates intracellular signaling involving PI3K/AKT and ETK pathways. This positively regulates transcription of IncRNA033862, such that sufficient transcript levels are present in the nucleus to activate the transcription of genes necessary for SSC self-renewal, such as Gfra1. (d) In the absence of GDNF, lower IncRNA033862 transcription, leading to reduced activation of Gfra1 transcription, causes imbalance of self-renewal and maintenance of SSCs. Error bars indicate S.D.

RNA-associated RNP complexes. ${ }^{50}$ In this study, we did not evaluate potential interactions of IncRNA033862 with miRNAs because of the exclusively nuclear localization of IncRNA033862, which would render such an association unlikely. We did not find significant protein partners of IncRNA033862 except for SCAMP1, which is a secretory carrier membrane protein located in the cell membrane. ${ }^{51}$ Based on these findings, we hypothesize that the positive effect of IncRNA033862 on Gfra1 transcription is mediated via RNA-chromatin interactions. Potential RNA-DNA interaction affecting gene transcription have also been reported in other recent studies. ${ }^{48,49,52,53}$ For example, TARID, an antisense IncRNA activates expression of the transcription factor TCF21 by inducing promoter demethylation. This appears to involve both interaction with the DNA demethylation factor GADD45A, but also possibly physical interaction of RNA with duplex DNA, forming an RNA:DNA triplex structure. Alternatively, TARID may associate with the TCF21 promoter by forming an R-loop, a characteristic structure of $\mathrm{CpG}$ island promoters. ${ }^{49}$ Our data reveal that IncRNA033862 has a positive regulator of growth factor receptor gene activity by RNA-DNA interaction, regulating SSC fate. Similar mechanisms of IncRNAmediated control of fate determination may exist in other types of stem cells. Although multiple IncRNAs have been identified, evidence for their regulatory functions has largely relied on in vitro studies, and so far, an essential function of IncRNAs has not been identified in vivo. Mutant mice with null mutations of abundant nuclear non-coding RNAs are viable and fertile. ${ }^{54,55}$ These findings suggest that IncRNAs are not essential during development or in the organism as a whole but have modulatory roles in particular tissues or under certain conditions. The in vivo transplantation experiments in our study strongly support the outcomes of in vitro analyses revealing IncRNA033862 regulates SSC fate; however, further exploration using in vivo genetic models is required to fully evaluate its role in the germline and other tissues. 
Collectively, our study provides the first evidence for a regulatory role of IncRNAs in SSCs, demonstrating that IncRNA033862 is essential for maintenance of SSC selfrenewal. Further exploring potential roles of in SSC fate regulation will be valuable to improve our understanding of the biology of SSCs, which are the only germline stem cells in the male gonad.

\section{Materials and Methods}

Germ cell isolation and culture. Long-term culture of SSC was established following a previously described protocol. ${ }^{31}$ Briefly, germ cells were isolated from 6- to 8-day-old C57BL/6 or B6;129S-Gt(Rosa) 26Sor/J mice (Jackson Laboratory, Bar Harbor, ME, USA), and Thy1-positive cells were enriched using magnetic-activated cell separation (Miltenyi Biotech, Bergisch Gladbach, Germany). Cells were plated at a density of 1.5 to $2 \times 10^{5}$ per well on 12-well plates with mitotically inactivated STO (SIM mouse embryo-derived thioguanine- and ouabainresistant feeder, SNLP76/7-4, ATCC, Manassas, VA, USA) feeder layers and cultured in a defined serum-free medium consisting of minimal essential medium (MEMa, Life Technology, Carlsbad, CA, USA) supplemented with $2 \%$ bovine serum albumin (BSA, Sigma-Aldrich, St. Louis, MO, USA), $20 \mathrm{ng} / \mathrm{ml}$ GDNF (R\&D Systems, Minneapolis, MN, USA), $150 \mathrm{ng} / \mathrm{ml}$ GFRA1 (R\&D Systems) and $1 \mathrm{ng} / \mathrm{ml}$ basic fibroblast growth factor (FGF2; BD Biosciences, San Jose, CA, USA), $10 \mu \mathrm{g} / \mathrm{ml}$ transferrin (Sigma-Aldrich), $50 \mu \mathrm{M}$ free fatty acid mixture (5.6 mM linolenic acid, $13.4 \mathrm{mM}$ oleic acid, $2.8 \mathrm{mM}$ palmitoleic acid, $35.6 \mathrm{mM}$ linoleic acid, $31.0 \mathrm{mM}$ palmitic acid, $76.9 \mathrm{mM}$ stearic acid; all from Sigma-Aldrich), $30 \mathrm{nM} \mathrm{Na}_{2} \mathrm{SeO}_{3}$ (Sigma-Aldrich), $2 \mathrm{mM}$ L-glutamine (Life Technology), $50 \mu \mathrm{M}$ 2-mercaptoethanol (Sigma-Aldrich), $5 \mu \mathrm{g} / \mathrm{ml}$ insulin (Sigma-Aldrich), $10 \mathrm{mM}$ HEPES (Sigma-Aldrich) and $60 \mu \mathrm{M}$ putrescine (Sigma-Aldrich). Cultures were maintained at $37^{\circ} \mathrm{C}$ in an incubator with humidified $5 \% \mathrm{CO}_{2}$ and $95 \%$ air atmosphere. Medium was replaced every 2-3 days and cells were passaged at a ratio of $1: 2$ or $1: 3$ every 5 to 6 days.

RNA isolation and sequencing. All reagents for RNA processing and experiments were prepared using DEPC water. For high-throughput sequencing, we used two lines of independently isolated and established SSCs that were subject to normal culture, $18 \mathrm{~h}$ of GDNF withdrawal and $18 \mathrm{~h}$ of GDNF withdrawal followed by replenishment of GDNF for $8 \mathrm{~h}$. Cells were gently dislodged and collected using a pipetting method that yields germ cell preparations of high (95\%) purity. ${ }^{19}$ Total RNA was isolated using Trizol reagent (Life Technology), followed by chloroform extraction and isopropanol precipitation. RNA preparations were depleted of rRNA and were fragmented into 200- to 500-bp molecules before synthesis of first-strand cDNA using random hexamer priming. The resulting CDNA libraries were sequenced using Illumina HiSeqTM 2000 (San Diego, CA, USA), followed by analysis and annotation of sequencing data using commercial services (BGI, Shenzhen, China). Known IncRNA species were identified by comparison with the NONCODE ncRNA library (http://noncode.org) using Cuffcompare software. ${ }^{37}$ To identify novel predicted IncRNAs, Coding Potential Calculator (CPC) ${ }^{36}$ was used.

Data deposition. The RNA sequencing data reported in this paper have been deposited in the National Center for Biotechnology Information Gene Expression Omnibus (GEO) database (GSE66998).

Quantitative gene expression. Primer sequences for RT-PCR and qRTPCR are listed in Supplementary Table 2. Quantitative RT-PCR analysis was performed using the StepOne plus real-time PCR system (StepOne Plus, Life Technology) and SYBR Premix Ex Taq II mixture (Takara Bio, Otsu, Japan) in a total volume of $20 \mu \mathrm{l}$ per well. Amplification conditions were $95^{\circ} \mathrm{C}$ for $30 \mathrm{~s}$ and 40 cycles of $95{ }^{\circ} \mathrm{C}$ for $5 \mathrm{~s}, 60{ }^{\circ} \mathrm{C}$ for $30 \mathrm{~s}$ and $60^{\circ} \mathrm{C}$ for $1 \mathrm{~min}$. Product specificity was verified by dissociation curve analysis and agarose gel electrophoresis.

In situ hybridization. A 794-bp RNA hybridization probe was designed against IncRNA033862 (5'start-3'end, 1604-2397 bp) and the corresponding fragment was amplified from mouse SSC cDNA (for oligonucleotide sequences see Supplementary Table 2) and cloned into pGEM-T vector (Promega, Madison, WI, USA). Sall-linearized plasmids were further purified and followed by in vitro transcription of Dig-labeled RNA probes according to the manufacturer instructions (Roche, Mannheim, Germany).
RNA in situ hybridization of $5 \mu \mathrm{m}$ cryosections of testis tissue from adult mice was performed as described previously, ${ }^{56}$ using $1.5 \mathrm{U} / \mathrm{ml}$ anti-digoxigenin-AP Fab fragments (Roche) and BCIP/NBT substrate (Promega) for probe detection.

Separation of nuclear and cytoplasmic fractions. Nuclear and cytoplasmic RNA fractions were isolated from $1 \times 10^{6}$ SSCs using the PARIS isolation kit (Life Technology) according to the manufacturer's instructions. Actin and small nuclear RNA U6 were used as controls for cytoplasmic and nuclear transcripts, respectively.

SSC transplantation. Transplantation was performed as previously described. ${ }^{41}$ Briefly, 50000 SSCs (GT-Rosa 26Sor/J) were transplanted into each testis of 129/SvCP $\times$ C57BL/6 hybrid male mice (Jackson Laboratory) that had been treated with $55 \mathrm{mg} / \mathrm{kg}$ busulfan (Sigma-Aldrich) 8 weeks before transplant to abolish endogenous spermatogenesis. Two months post transplant, testes were harvested and donor cell-derived spermatogenetic colonies identified using 5-bromo-4-chloro3-indolyl-beta-o-galactoside (X-gal; Sigma-Aldrich) staining.

Lentivirus-mediated IncRNA silencing. The pLKO.1 shRNA lentivirus vector and lentivirus packaging plasmids (pmd-REV and pmd-1G/pmd-LG) were provided by Dr. Chen Dahua ${ }^{57}$ (State Key Laboratory of Reproductive Biology, Beijing, China). The vector plasmid contains a puromycin selection site and a U6 Pollll promoter sequence for the introduction of oligonucleotides encoding shRNAs. We designed two different shRNAs for LncRNA033862 knockdown; these were mus-XLOC_033862-663shRNA directed against nucleotides 663-683 and mus-XLOC_033862-1894 shRNA directed against nucleotides 1894-1914 of IncRNA033862 (see Supplementary Table 2).

Lentivirus particles were generated by co-transfection of shRNA plasmids and lentivirus packaging plasmids into $\mathrm{HEK} 293 \mathrm{~T}$ cells using $\mathrm{CaCl}_{2}$ transfection following a protocol provided by Addgene (http://www.addgene.org/tools/protocols/plko/). Virus particles were harvested $48 \mathrm{~h}$ after transfection. For viral transduction, 300000 SSCs were plated onto 12-well plates pre-coated with $0.1 \%$ gelatin (Sigma-Aldrich) and incubated with a 1:1 mixture of culture medium and viral supernatant, supplemented with $5 \mu \mathrm{g} / \mathrm{ml}$ polybrene. After overnight transduction, cells were re-plated onto STO feeder layers and cultured in SSC medium. RNA was isolated $72 \mathrm{~h}$ after lentiviral transduction.

Polysome assay. Testis lysates were prepared from $20 \mathrm{P} 10$ testes in buffer containing $100 \mathrm{mM} \mathrm{KCl}, 0.1 \%$ Triton X-100, $50 \mathrm{mM}$ HEPES, $2 \mathrm{mM} \mathrm{MgCl}, 10 \%$ glycerol, $1 \mathrm{mM}$ DTT, $20 \mathrm{U} / \mathrm{ml}$ Protector RNase Inhibitor (Promega) and $1 \times$ EDTAfree protease inhibitor cocktail (Roche). Lysate was kept on ice for $15 \mathrm{~min}$ and centrifuged at $10000 \mathrm{~g}$ for $10 \mathrm{~min}$. The supernatant was loaded on 20 to $50 \% \mathrm{w} / \mathrm{v}$ linear density sucrose gradient (Gradient Master, Biocomp, Fredericton, NB, Canada) and centrifuged by 38000 r.p.m. for $3 \mathrm{~h}$ (Beckman Coulter Optima L-100 XP Ultracentrifuge, Brea, CA, USA), followed by collection of RNP, 40S to 80 S ribosome and polysome fractions using a piston gradient fractionator (Biocomp). For quantitative RT-PCR analysis of IncRNA and mRNA species, total RNAs were isolated from $200 \mu \mathrm{l}$ of each fraction. The efficiency of polysome separation was verified by western blot analysis of individual fractions using antibodies directed against ribosomal protein L22 (Novus, Littleton, CO, USA) and tubulin (Cell Signaling, Danvers, MA, USA).

Chromatin isolation by RNA purification. For affinity capture of complexes containing IncRNA033862 and chromatin, we designed 10 tiled antisense probes covering the sequence of XLOC033862 using an online design tool (www.singlemoleculefish.com). Probes were numbered according to their position and separated into two pools containing either odd (1, 3, 5, 7 and 9) or even-numbered probes $(2,4,6,8$ and 10; for sequences see Supplementary Table 2).

ChIRP was performed according to a previously published protocol. ${ }^{58}$ Briefly, approximately 25-30 million cells were harvested and cross-linked with $1 \%$ glutaraldehyde (Sigma-Aldrich) for 10 min prior followed by quenching with $1.25 \mathrm{M}$ glycine for $5 \mathrm{~min}$. Cell pellets were collected by centrifugation and lysed in a buffer containing $50 \mathrm{mM}$ Tris, $10 \mathrm{mM}$ EDTA, 1\% SDS, $1 \mathrm{mM}$ PMSF (Sigma-Aldrich), 1x Protease inhibitor (Roche) and $0.1 \mathrm{U} / \mu \mathrm{l}$ RNAse inhibitor (Life Technology). Lysates were sonicated to shear the DNA to lengths of $100-500$ bp using an Ultrasonic Broken Instrument (Branson, Shanghai, China) in a $4^{\circ} \mathrm{C}$ water bath at a setting of 10 cycles for $20 \mathrm{~s}$, interspersed with a rest period of $30 \mathrm{~s}$. Sonicated samples were continuously centrifuged at $16100 \mathrm{~g}$ for $10 \mathrm{~min}$ at $4{ }^{\circ} \mathrm{C}$. Supernatants were 
hybridized separately with each of the two pools of 3'-biotinylated probes (GenScript, Suzhou, China; $1 \mu \mathrm{l}$ of $100 \mathrm{pmol} / \mu \mathrm{l}$ probes per $1 \mathrm{ml}$ chromatin) in a buffer consisting of $500 \mathrm{mM} \mathrm{NaCl}, 1 \%$ SDS, $100 \mathrm{mM}$ Tris $7.0,10 \mathrm{mM}$ EDTA, $15 \%$ formamide, $1 \mathrm{mM}$ PMSF, $1 \mathrm{x}$ protease inhibitor and RNAse inhibitor at $37^{\circ} \mathrm{C}$ for $4 \mathrm{~h}$ with gently shaking. Following hybridization, samples were incubated with Dynabeads MyOne Streptavidin $\mathrm{C} 1$ (Life Technology) at $37^{\circ} \mathrm{C}$ for $30 \mathrm{~min}$. After five washes in $2 \times \mathrm{SSC}$ (Life Technology) supplemented with $0.5 \%$ SDS and $1 \mathrm{mM}$ PMSF, beads with conjugated RNP-chromatin complexes were separated using a DynaMag-2 magnetic strip (Life Technology).

Immunofluorescence. Cultured SSCs were fixed with $4 \%$ paraformaldehyde for $15 \mathrm{~min}$, and blocked with $1 \%$ BSA containing $0.1 \%$ Triton X-100 in DPBS buffer for $1 \mathrm{~h}$ at room temperature. After incubation with primary antibodies against PLZF (1:100; R\&D Systems) and LIN28A (1 : 100; Abcam, Cambridge, MA, USA) for 2$3 \mathrm{~h}$ at room temperature, cells were washed $3 \mathrm{x}$ with DPBS, followed by incubation with secondary antibodies (bovine anti-goat-TRITC 1: 1000 and donkey anti-rabbitFITC $1: 1000$ ) for $1-2 \mathrm{~h}$. Samples were analyzed using confocal microscopy (LSM 700, Zeiss, Pleasanton, CA, USA).

Data processes and statistical analysis. Image data were assembled using Adobe Photoshop 7.0 software (Adobe, San Jose, CA, USA). LncRNA expression analyses were performed by BIG Company (BGI, Shenzhen, China) as reported previously; ${ }^{59} P$-values correspond to differential gene expression tests and false discovery rate (FDR) was used to determine the threshold of $P$-value in multiple tests. Sequencing, gene expression, transfection and transplantation experiments were performed in duplicate or triplicate using independently established SSCs cultures. Differences between groups were determined by oneway ANOVA using SPSS 16.0 statistical software (SPSS, Armonk, NY, USA). A difference was considered significant when the $P$-value was $<0.05$.

\section{Conflict of Interest}

The authors declare no conflict of interest.

Acknowledgements. We thank Dr. Eugene Xu, Dr. Lan Ye, Ke Zheng for critical evaluation of the manuscript and Dr. S. Eckardt for help with manuscript preparation. This study was supported by National Natural Science Foundation of the People's Republic of China grant 31271581; 31571537, National Key Basic Research Program grant (973 grant, 2013CB945201), Natural Science Foundation of Jiangsu Province (BK2012837) and Research Foundation for the Doctoral Program of Higher Education of China (20123234120013).

\section{Author contributions}

L Li, Min Wang, X Wu designed research; Min Wang, Mei Wang, XX Wu, L Li, L Geng, $Y$ Xue, $X$ Wei and $Y$ Jia performed research; Min Wang, Mei Wang, L Li, XX Wu, L Geng, $X$ Wu analyzed data and M Wang, $L \mathrm{Li}, \mathrm{X}$ Wu wrote the paper. All authors approved the final manuscript.

1. de Rooij DG. Stem cells in the testis. Int J Exp Pathol 1998; 79: 67-80.

2. Brinster RL, Zimmermann JW. Spermatogenesis following male germ-cell transplantation. Proc Natl Acad Sci USA 1994; 91: 11298-11302.

3. Kanatsu-Shinohara M, Ogonuki N, Inoue K, Miki H, Ogura A, Toyokuni S et al. Long-term proliferation in culture and germline transmission of mouse male germline stem cells. Biol Reprod 2003; 69: 612-616.

4. Kubota H, Avarbock MR, Brinster RL. Growth factors essential for self-renewal and expansion of mouse spermatogonial stem cells. Proc Natl Acad Sci USA 2004; 101: 16489-16494.

5. Oatley JM, Oatley MJ, Avarbock MR, Tobias JW, Brinster RL. Colony stimulating factor 1 is an extrinsic stimulator of mouse spermatogonial stem cell self-renewal. Development 2009; 136: 1191-1199.

6. Yeh JR, Zhang X, Nagano MC. Wnt5a is a cell-extrinsic factor that supports self-renewal of mouse spermatogonial stem cells. J Cell Sci 2011; 124: 2357-2366.

7. Morimoto H, Iwata K, Ogonuki N, Inoue K, Atsuo O, Kanatsu-Shinohara M et al. ROS are required for mouse spermatogonial stem cell self-renewal. Cell Stem Cell 2013; 12 : 774-786.

8. Meng X, Lindahl M, Hyvönen ME, Parvinen M, de Rooij DG, Hess MW et al. Regulation of cell fate decision of undifferentiated spermatogonia by GDNF. Science 2000; 287: 1489-1493.

9. Ryu BY, Kubota H, Avarbock MR, Brinster RL. Conservation of spermatogonial stem cell self-renewal signaling between mouse and rat. Proc Natl Acad Sci USA 2005; 102 : 14302-14307.
10. Kubota H, Wu X, Goodyear SM, Avarbock MR, Brinster RL. Glial cell line-derived neurotrophic factor and endothelial cells promote self-renewal of rabbit germ cells with spermatogonial stem cell properties. FASEB J 2011; 25: 2604-2614.

11. Kanatsu-Shinohara M, Muneto T, Lee J, Takenaka M, Chuma S, Nakatsuji N et al. Long-term culture of male germline stem cells from hamster testes. Biol Reprod 2008; 78: 611-617.

12. He Z, Kokkinaki M, Jiang J, Dobrinski I, Dym M. Isolation, characterization, and culture of human spermatogonia. Biol Reprod 2010; 82: 363-372.

13. Sadri-Ardekani H, Mizrak SC, van Daalen SK, Korver CM, Roepers-Gajadien HL, Koruji $\mathrm{M}$ et al. Propagation of human spermatogonial stem cells in vitro. JAMA 2009; 302 : 2127-2134.

14. He Z, Jiang J, Kokkinaki M, Golestaneh N, Hofmann MC, Dym M. Gdnf upregulates c-Fos transcription via the Ras/Erk1/2 pathway to promote mouse spermatogonial stem cell proliferation. Stem Cells 2008; 26: 266-278.

15. Oatley JM, Avarbock MR, Brinster RL. Glial cell line-derived neurotrophic factor regulation of genes essential for self-renewal of mouse spermatogonial stem cells is dependent on $\mathrm{Src}$ family kinase signaling. J Biol Chem 2007; 282: 25842-25851.

16. Lee J, Kanatsu-Shinohara M, Morimoto H, Kazuki Y, Takashima S, Oshimura M et al. Genetic reconstruction of mouse spermatogonial stem cell self-renewal in vitro by Ras-cyclin D2 activation. Cell Stem Cell 2009; 5: 76-86.

17. Lee J, Kanatsu-Shinohara M, Inoue K, Ogonuki N, Miki H, Toyokuni S et al. Akt mediates self-renewal division of mouse spermatogonial stem cells. Development 2007; 134: 1853-1859.

18. Wu X, Goodyear SM, Tobias JW, Avarbock MR, Brinster RL. Spermatogonial stem cell selfrenewal requires ETV5-mediated downstream activation of Brachyury in mice. Biol Reprod 2011; 85: 1114-1123.

19. Oatley JM, Avarbock MR, Telaranta AI, Fearon DT, Brinster RL. Identifying genes important for spermatogonial stem cell self-renewal and survival. Proc Natl Acad Sci USA 2006; 103: 9524-9529.

20. Buaas FW, Kirsh AL, Sharma M, McLean DJ, Morris JL, Griswold MD et al. Plzf is required in adult male germ cells for stem cell self-renewal. Nat Genet 2004; 36: 647-652.

21. Costoya JA, Hobbs RM, Barna M, Cattoretti G, Manova K, Sukhwani M et al. Essential role of Plzf in maintenance of spermatogonial stem cells. Nat Genet 2004; 36: 653-659.

22. Goertz MJ, Wu Z, Gallardo TD, Hamra FK, Castrillon DH. Foxo1 is required in mouse spermatogonial stem cells for their maintenance and the initiation of spermatogenesis. J Clin Invest 2011; 121: 3456-3466.

23. Niu Z, Goodyear SM, Rao S, Wu X, Tobias JW, Avarbock MR et al. MicroRNA-21 regulates the self-renewal of mouse spermatogonial stem cells. Proc Natl Acad Sci USA 2011; 108: 12740-12745.

24. He Z, Jiang J, Kokkinaki M, Tang L, Zeng W, Gallicano I et al. MiRNA-20 and mirna-106a regulate spermatogonial stem cell renewal at the post-transcriptional level via targeting STAT3 and Ccnd1. Stem Cells 2013; 31: 2205-2217.

25. Yang QE, Racicot KE, Kaucher AV, Oatley MJ, Oatley JM. MicroRNAs 221 and 222 regulate the undifferentiated state in mammalian male germ cells. Development 2013; 140: 280-290.

26. Tong MH, Mitchell D, Evanoff R, Griswold MD. Expression of Mirlet7 family microRNAs in response to retinoic acid-induced spermatogonial differentiation in mice. Biol Reprod 2011; 85: 189-197.

27. Faghihi MA, Wahlestedt $\mathrm{C}$. Regulatory roles of natural antisense transcripts. Nat Rev Mol Cell Biol 2009; 10: 637-643.

28. Guttman M, Donaghey J, Carey BW, Garber M, Grenier JK, Munson G et al. LincRNAs act in the circuitry controlling pluripotency and differentiation. Nature 2011; 477: 295-300.

29. Wang $Y, X u Z$ Z, Jiang J, Xu C, Kang J, Xiao L et al. Endogenous miRNA sponge lincRNA-RoR regulates Oct4, Nanog, and Sox2 in human embryonic stem cell self-renewal. Dev Cell 2013; 25: $69-80$.

30. Cesana M, Cacchiarelli D, Legnini I, Santini T, Sthandier O, Chinappi M et al. A long noncoding RNA controls muscle differentiation by functioning as a competing endogenous RNA. Cell 2011; 147: 358-369.

31. Kubota $H, B$ Binster RL. Culture of rodent spermatogonial stem cells, male germline stem cells of the postnatal animal. Methods Cell Biol 2008; 86: 59-84.

32. Wu X, Goodyear SM, Abramowitz LK, Bartolomei MS, Tobias JW, Avarbock MR et al. Fertile offspring derived from mouse spermatogonial stem cells cryopreserved for more than 14 years. Hum Reprod 2012; 27: 1249-1259.

33. Chakraborty P, Buaas FW, Sharma M, Snyder E, de Rooij DG, Braun RE. LIN28A marks the spermatogonial progenitor population and regulates its cyclic expansion. Stem Cells 2014; 32: 860-873.

34. Chan F, Oatley MJ, Kaucher AV, Yang QE, Bieberich CJ, Shashikant CS et al. Functional and molecular features of the Id4+ germline stem cell population in mouse testes. Genes Dev 2014; 28: 1351-1362.

35. Oatley JM, Brinster RL. Regulation of spermatogonial stem cell self-renewal in mammals. Annu Rev Cell Dev Biol 2008; 24: 263-286.

36. Kong $L$, Zhang $Y$, Ye ZQ, Liu $X Q$, Zhao $S Q$, Wei $L$ et al. CPC: assess the protein-coding potential of transcripts using sequence features and support vector machine. Nucleic Acids Res 2007; 35: W345-W349.

37. Trapnell C, Williams BA, Pertea G, Mortazavi A, Kwan G, van Baren MJ et al. Transcript assembly and quantification by RNA-Seq reveals unannotated transcripts and isoform switching during cell differentiation. Nat Biotechnol 2010; 28: 511-515. 
38. Jin J, Jing W, Lei XX, Feng C, Peng S, Boris-Lawrie $\mathrm{K}$ et al. Evidence that Lin28 stimulates translation by recruiting RNA helicase A to polysomes. Nucleic Acids Res 2011; 39 : 3724-3734.

39. Gandin V, Sikström K, Alain T, Morita M, McLaughlan S, Larsson O et al. Polysome fractionation and analysis of mammalian translatomes on a genome-wide scale. $J$ Vis Exp 2014: 87: 1-9.

40. He Z, Jiang J, Hofmann MC, Dym M. Gfra1 silencing in mouse spermatogonial stem cells results in their differentiation via the inactivation of RET tyrosine kinase. Biol Reprod 2007; 77: 723-733.

41. Ogawa T, Aréchaga JM, Avarbock MR, Brinster RL. Transplantation of testis germinal cells into mouse seminiferous tubules. Int J Dev Biol 1997; 41: 111-122.

42. Nakagawa T, Sharma M, Nabeshima Y, Braun RE, Yoshida S. Functional hierarchy and reversibility within the murine spermatogenic stem cell compartment. Science 2010; 328: $62-67$.

43. Buageaw A, Sukhwani M, Ben-Yehudah A, Ehmcke J, Rawe VY, Pholpramool C et al. GDNF family receptor alpha1 phenotype of spermatogonial stem cells in immature mouse testes. Biol Reprod 2005; 73: 1011-1016.

44. Naughton CK, Jain S, Strickland AM, Gupta A, Milbrandt J. Glial cell-line derived neurotrophic factor-mediated RET signaling regulates spermatogonial stem cell fate. Biol Reprod 2006; 74: 314-321.

45. Pandey RR, Mondal T, Mohammad F, Enroth S, Redrup L, Komorowski J et al. Kcnq1 ot1 antisense noncoding RNA mediates lineage-specific transcriptional silencing through chromatin-level regulation. Mol Cell 2008; 32: 232-246.

46. Yu W, Gius D, Onyango P, Muldoon-Jacobs K, Karp J, Feinberg AP et al. Epigenetic silencing of tumour suppressor gene $p 15$ by its antisense RNA. Nature 2008; 451: 202-206.

47. Pang WJ, Lin LG, Xiong Y, Wei N, Wang Y, Shen QW et al. Knockdown of PU. 1 AS IncRNA inhibits adipogenesis through enhancing PU.1 mRNA translation. J Cell Biochem 2013; 114: 2500-2512.

48. Vigetti D, Deleonibus S, Moretto P, Bowen T, Fischer JW, Grandoch M et al. Natural antisense transcript for hyaluronan synthase 2 (HAS2-AS1) induces transcription of HAS2 via protein O-GlcNAcylation. J Biol Chem 2014; 289: 28816-28826.

49. Arab K, Park YJ, Lindroth AM, Schäfer A, Oakes C, Weichenhan D et al. Long noncoding RNA TARID directs demethylation and activation of the tumor suppressor TCF21 via GADD45A. Mol Cell 2014; 55: 604-614.

50. Batista PJ, Chang HY. Long noncoding RNAs: cellular address codes in development and disease. Cell 2013; 152: 1298-1307.
51. Fernández-Chacón R, Alvarez de Toledo G, Hammer RE, Südhof TC. Analysis of SCAMP1 function in secretory vesicle exocytosis by means of gene targeting in mice. J Biol Chem 1999; 274: 32551-32554.

52. Sun J, Li W, Sun Y, Yu D, Wen X, Wang H et al. A novel antisense long noncoding RNA within the IGF1R gene locus is imprinted in hematopoietic malignancies. Nucleic Acids Res 2014; 42: 9588-9601.

53. Kim T, Cui R, Jeon YJ, Lee JH, Lee JH, Sim H et al. Long-range interaction and correlation between MYC enhancer and oncogenic long noncoding RNA CARLo-5. Proc Natl Acad SC USA 2014; 111: 4173-4178.

54. Eißmann M, Gutschner T, Hämmerle M, Günther S, Caudron-Herger M, Groß M et al. Loss of the abundant nuclear non-coding RNA MALAT1 is compatible with life and development. RNA Biol 2012; 9: 1076-1087.

55. Nakagawa S, Naganuma T, Shioi G, Hirose T. Paraspeckles are subpopulation-specific nuclear bodies that are not essential in mice. J Cell Biol 2011; 193: 31-39.

56. Powner MB, Vevis K, McKenzie JA, Gandhi P, Jadeja S, Fruttiger M. Visualization of gene expression in whole mouse retina by in situ hybridization. Nat Protoc 2012; 7: 1086-1096.

57. Xia L, Jia S, Huang S, Wang H, Zhu Y, Mu Y et al. The Fused/Smurf complex controls the fate of Drosophila germline stem cells by generating a gradient BMP response. Cell 2010; 143: 978-990.

58. Chu C, Quinn J, Chang HY. Chromatin isolation by RNA purification (ChIRP). J Vis Exp 2012; 61: 1-6.

59. Tarazona S, García-Alcalde F, Dopazo J, Ferrer A, Conesa A. Differential expression in RNA-seq: a matter of depth. Genome Res 2011; 21: 2213-2223.

(i) Cell Death and Disease is an open-access journal published by Nature Publishing Group. This work is licensed under a Creative Commons Attribution 4.0 International License. The images or other third party material in this article are included in the article's Creative Commons license, unless indicated otherwise in the credit line; if the material is not included under the Creative Commons license, users will need to obtain permission from the license holder to reproduce the material. To view a copy of this license, visit http://creativecommons.org/licenses/by/4.0/

Supplementary Information accompanies this paper on Cell Death and Disease website (http://www.nature.com/cddis) 